\title{
Diversity of Weevils (Coleoptera) in Marahan, Marilog Forest Reserve, Southern Mindanao, Philippines
}

\author{
Alma B. Mohagan, Romeo R. Patano Jr.*, Merced G. Melencion, Daryl S. Salas, Fulgent P. Coritico, \\ Victor B. Amoroso \\ Center for Biodiversity Research and Extension in Mindanao, Department of Biology, Central Mindanao Univer- \\ sity, Musuan, Maramag, Bukidnon 8710, Philippines
}

Article history:

Submission May 2020

Revised July 2020

Accepted September 2020

*Corresponding author:

E-mail:

romeonojrpatano@gmail.com

\begin{abstract}
Fieldworks were conducted last January to March, 2019 to collect and record species of weevils at Sitio Matigsalug, Marahan, Marilog Forest Reserve, Marilog District, Mindanao, Philippines. Standard sampling techniques such as belt transect and opportunistic sampling were conducted in the established 2 kilometers transect to survey the agroforest and montane ecosystems with elevations of 800-950 masl and 1,000-1,300 masl, respectively. A total of 228 individuals belonging to 2 families and 22 species of weevils were recorded, all of which are only known from forest and mountain ecosystems of Mindanao. Metapocrytus is the most encountered genus with 12 species. The montane forest had higher species richness with 15 species but with lower species abundance of 34 individuals compared to the agroforest ecosystem with 13 species and 194 individuals. Seven (7) species are common in both sites. Plant associates and behavior of the observed weevils were also noted which include 22 species of ferns and flowering plants. Other than perching behavior, species are also observed copulating, feeding and mostly hiding in abaxial part of leaves. As flightless beetles with high vulnerability for predation by other insectivorous species, the observations gathered will help in understanding their behaviors for survival. Despite of high species richness and abundance, anthropogenic disturbances such as agricultural activities are on-going which extend towards the montane forest in the area. Conservation initiatives must be implemented to protect the remaining endemic and rare species of flora and fauna.
\end{abstract}

Keywords: Endemic, Marilog District, Metapocyrtus, Montane forest, Pachyrhynchus

\section{Introduction}

The Philippines is considered one of the mega diverse tropical countries due to its very high endemicity and richness of flora and fauna [1]. Some of which are the interesting group of insects called weevils. They are group of beetles with an estimated endemicity of more than $90 \%$ and with a Philippine centered distribution [2, 3]. Currently, there are more than 51,000 species of weevils in 4,600 genera in which Philippines contributes more than 400 species [4]. Discoveries on new species of Philippine weevils was prominently conducted by taxonomists from other countries $[5,6,7,8,9]$ but recently more dis- coveries were published by Filipino taxonomists and systematists specifically from the genera Pachyrhynchus and Metapocyrtus [9, 10, 11].

At present, over 100 species of weevils from the genus Pachyrhynchus Germar and over 200 from the genus Metapocyrtus Heller were recorded in the Philippines [6, 13]. Inventory and diversity studies of weevils were conducted in some parts of Mindanao [13, 14, 15]. These studies showcased different endemic and rare species of weevils. These studies implied that weevils are highly restricted in a specific area which supports their high endemicity. Ecological aspects of these

\section{How to cite:}

Mohagan AB, Patano Jr. RR, Melencion MG et al. (2020) Diversity of Weevils (Coleoptera) in Marahan, Marilog Forest Reserve, Southern Mindanao, Philippines. Journal of Tropical Life Science 10 (3): 259 - 270. doi: 10.11594/jtls.10.03.10. 
species are still poorly understood. Plant associates of Mindanao weevils were first studied by Ballentes et al. (2006) but the behaviors of those were not elaborated. Although studies had been already conducted when it comes to their diversity and distribution, there are still remote and inaccessible areas including Sitio Matigsalug that houses undocumented species.

Thus, this study was done to provide the species composition, diversity, plant associates and common behaviors of weevils in Sitio Matigsalug, Marahan, Marilog Forest Reserve, Marilog District, Southern Philippines.

\section{Material and Methods Sampling sites}

Sitio Matigsalug, Marilog District was surveyed from January to March 2019, primarily its agroforest and montane forest ecosystems (Figure 1). This area was surveyed due to its intact forest and vegetation. There are no recent published data in these unexplored areas because of its inaccessibility. Disturbances in the area were observed such as agricultural activities and clearing of land area for housing purposes. Sitio Matigsalug is at the eastern side of Marilog District which is about 8-10 kilometers away from the main road $\left(7^{\circ} 26^{\prime} 13.22^{\prime \prime} \mathrm{N}, 125^{\circ} 15^{\prime} 50.42^{\prime \prime} \mathrm{E}\right)$. The area is composed of 7 distinct ridges which are considered as montane forest surrounded by agroforest ecosystem due to shifting cultivation of farm crops such as Sechium edule L., Basella alba (Jacq.) Swartz and Zea mays L. by the indigenous people.

The area is dominated by tall trees of Lithocarpus spp. and the invasive shrub Piper aduncum L. The understory plants are primarily dominated by ferns such as Dicranopteris linearis (Burm.f.) Underw. and aroids such as Alocasia spp. Leaf litter was not so thick. The area surveyed has an altitudinal range of $800-1,300$ m.a.s.l (Figure 2).

\section{Collection of weevils}

The standard belt-transect sampling method [16] with combination of random and opportunistic sampling was employed in the study. The collection of weevils was conducted along the transect covering 10 meters (5 meters on both sides). Specimens were collected through handpicked whenever encountered during the diurnal (0700$1500)$ and nocturnal (1700-2200) searches and

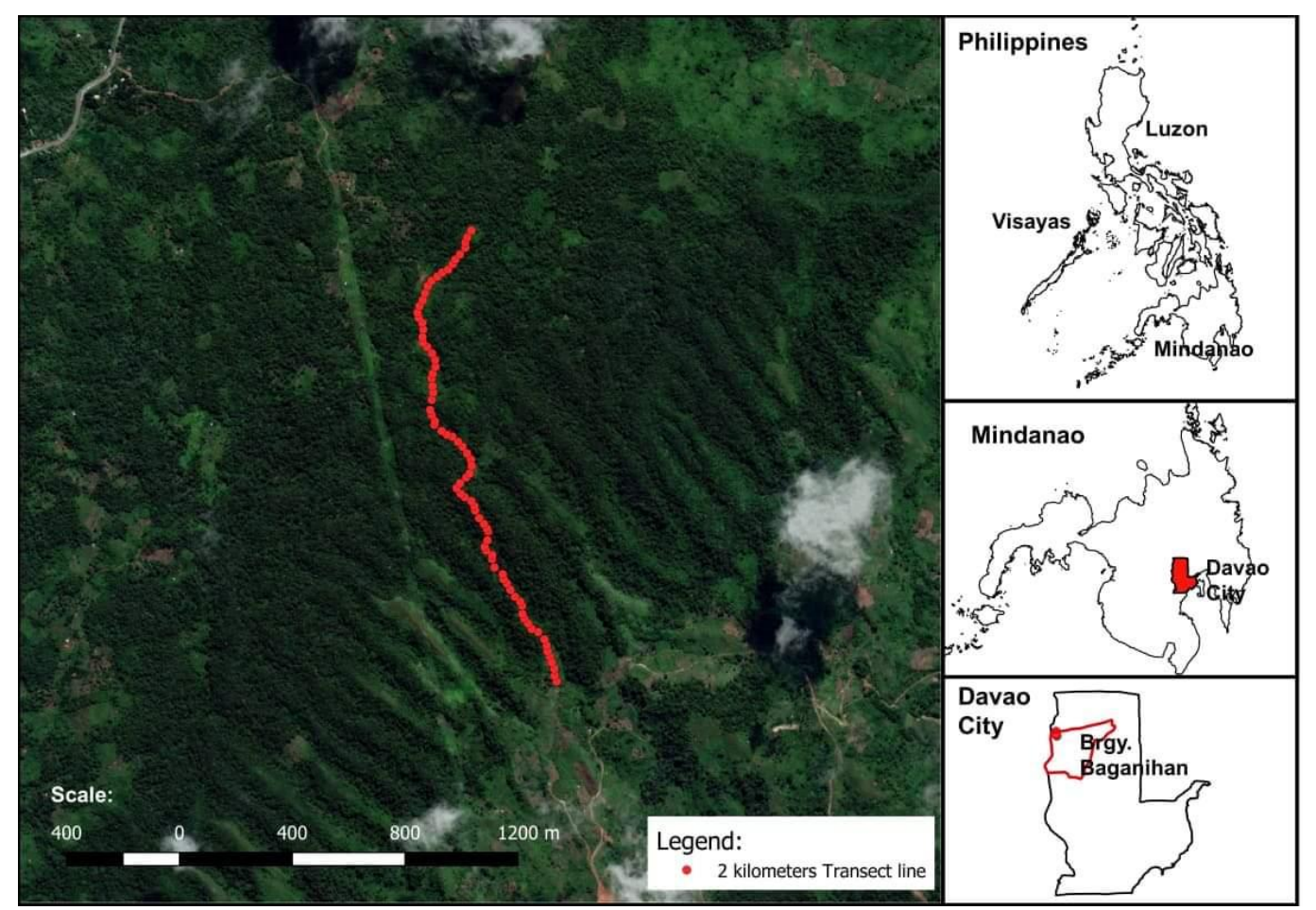

Figure 1. Map of the Philippines, Mindanao and Davao City showing the location of the study site and the 2 kilometers transect (red points) in Sitio Matigsalug, Marahan, Marilog Forest Reserve, Marilog District $\left(7^{\circ} 26^{\prime} 13.22^{\prime \prime} \mathrm{N}, 125^{\circ} 15^{\prime} 50.42^{\prime \prime} \mathrm{E}, 800-1,300\right.$ m.a.s.l.) 


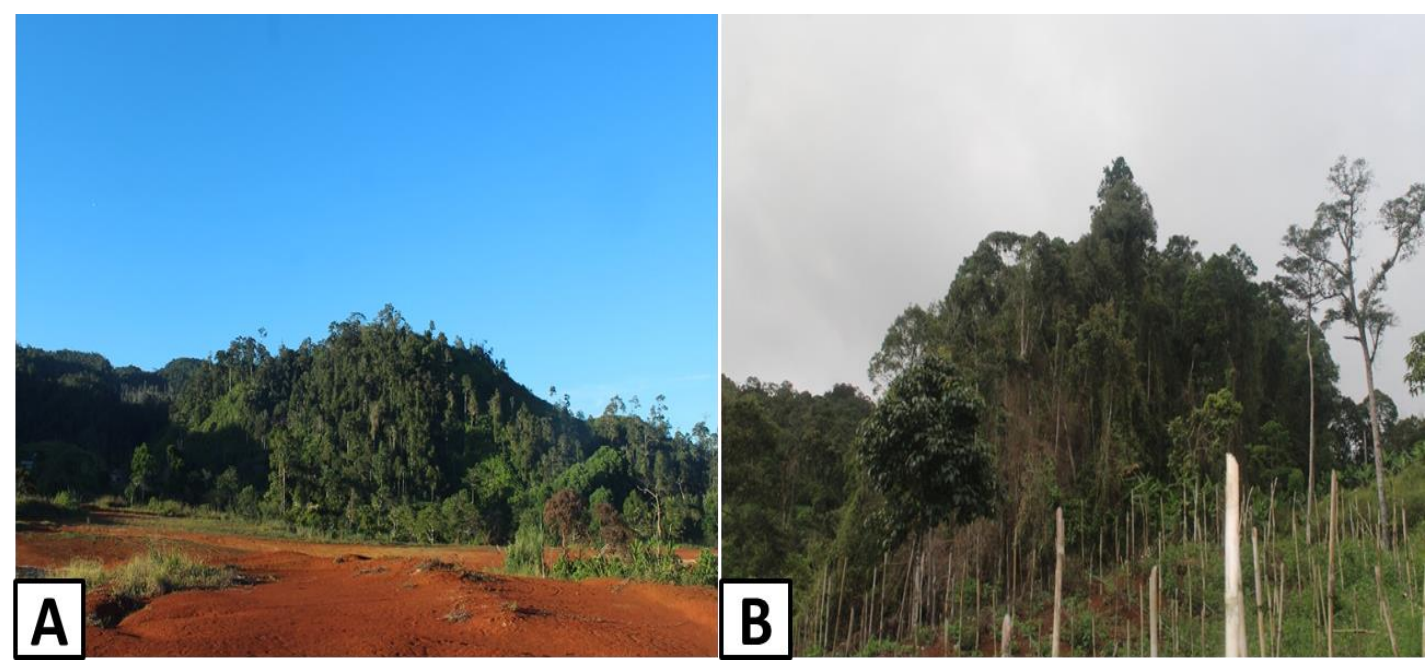

Figure 2. Forest patches in Sitio Matigsalug, Marahan Proper, Marilog District, Davao City (A and B)

placed in modified jars with ethyl acetate. Collected specimens were then preserved in 95\% ethyl alcohol and brought to the laboratory, airdried and photographed under a stereomicroscope. A maximum of 3 individuals per species was collected in accordance to the Gratuitous Permit issued by the DENR.

\section{Composition, relative abundance, plant associ- ates and ecological notes}

Other important data such as relative abundance and plant associates of weevil species were recorded. Relative abundance of each species is presented as percentage. The values were taken by dividing the number of individuals per species to the total number of individuals observed for all species then multiplied by 100 . Plant associates of each species were photographed and identified by a plant taxonomist (FPC; one of the authors). Notable behaviors and activities of each species were also observed and noted.

\section{Identification and Diversity analysis}

Published articles, taxonomic keys and monographs of Schultze (1923), Yoshitake (2012b) and Rukmane and Barsevskis (2016) were used for the identification of the collected and observed specimens. Bio Pro software version 2.0 was used in producing Shannon-weiner diversity indices of the agroforest and montane forest ecosystems.

\section{Results and Discussions Species Richness and Abundance}

The faunistic inventory of weevils revealed a total of 228 observed and collected individuals comprising 22 species and six (6) genera from the agroforest and montane forest of Sitio Matigsalug, Marilog Forest Reserve. Three (3) species belong to the genus Pachyrhynchus, twelve (12) species of Metapocyrtus, four (4) species belongs to the genus Alcidodes and one (1) species from each genera Desmidophorus, Peribleptus and Polycatus. All of the species belong to the family Curculionidae except for the species Desmidophorus sp. from the family Brachyceridae (Table 1 and 2).

The genus Metapocyrtus Heller had the highest species abundance comprising 185 individuals followed by genus Alcidodes Marshall with 12 individuals, genus Polycatus Heller with 18 individuals, genus Pachyrhynchus Germar with six individuals, genus Desmidophorus Dejean with four individuals and lastly, the genus Peribleptus Schoenherr with only three individuals. Species richness revealed that the montane forest had the higher number of species (15 spp.) compared to agroforest ecosystem (13 spp.) which is mostly dominated by the genus Metapocyrtus while the species abundance revealed that the agroforest ecosystem had the higher number of individuals (194) compared to montane forest (34 individuals) (Figure 3). Genus Alcidodes comprising four morpho-species are just observed in montane forest with a total of 12 individuals in which Alcidodes sp. 3 is the most common species with five (5) individuals. These species can be considered as specific on its habitat as this are recorded only in montane forest. Desmidophorus sp. is the only one species from the family Brachyceridae which 




Figure 3. Collected specimens in Sitio Matigsalug, Marahan, Marilog Forest Reserve, Marilog District, Davao City, Mindanao, Philippines. A. Peribleptus sp.; B. Polycatus sp.; C. Metapocrytus kitangladensis; D. Alcidodes sp.4; E. Metapocyrtus sp.3; F. Metapocyrtus sp.4; G. Metapocrytus sp.5; H. Metapocyrtus sp.6; I. Metapocyrtus sp.7; J. Metapocyrtus sp.8; K. Desmidophorus sp. and L. Metapocyrtus apoensis 
are morphologically unique due to its oval shape body almost covered with scales with geniculate antennae [19]. Four individuals of this species are only observed in agroforest.

Metapocyrtus is the most common genus both in agroforest and montane ecosystem with a total of twelve species in which 8 are morphospecies. All known Metapocyrtus species are endemic in the Philippines. Eleven species are observed in agroforest ecosystem while only 7 species are observed in montane forest ecosystem. According to Cabras et al. (2017), Metapocyrtus species have high adaptability to environmental changes and with no specific food preference which enable these species to survive to wide ranges of habitat types especially in lower elevation. This explains why more Metapocyrtus species are recorded in agroforest compared to montane forest ecosystem.

There are only 3 Pachyrhynchus species observed in the study all from montane forest ecosystem as these species are observed only in specific habitat with higher elevation. There are 2 known species namely, $P$. miltoni and $P$. erichsoni, and only 1 morpho-species recorded which reflects to the rarity of the species belonging to the genus. There are more than a hundred of described species of Pachyrhynchus endemic to the Philippines as there are recently described new species endemic in Mindanao.

Polycatus sp. is another common species observed only in agroforest ecosystem with a total of 18 observed and collected individuals. Lastly, the genus Peribleptus which was observed only in montane forest with only 3 individuals. These genera formulated and described by Heller (1922) are those undocumented and not well studied species in the archipelago. Thus, the present study provides new locality record of these genera.

In comparison to the number of species belonging to family Curculionidae documented from the neighboring mountain and forest ecosystems, the present study provides higher species richness compared to Mt. Kiamo (20) but with a lower number of species compared to its nearby forest ecosystem in Baganihan (23) with 2 shared species (P. miltoni and M. apoensis) and Mt. Malindang (31). However, the study had same number of species with Mt. Apo (21) in which 2 same species (P. erichsoni and M. apo- ensis) is also recorded in the area.

\section{Diversity}

Species accumulation curve showed that only agroforest ecosystem reached asymptote which indicates that all of the species are well represented and there are still species that were not documented in the montane forest ecosystem. Diversity assessment revealed that montane forest had higher diversity index with $\mathrm{H}=1.12$ compared to agroforest ecosystem (Table 2). This is more likely due to availability food and microhabitat present in the montane forest, while anthropogenic disturbances are very common in agroforest ecosystem. The small difference in the indices across sites might due to Metapocyrtus spp. enables to dwell to the wide range of environments and also to the availability of food in the agroforest ecosystem. Nine (9) unique species are just recorded in montane forest ecosystem. This implies that these species inhabits montane forest, more likely primary or secondary montane forest, and won't able to survive in an agroforest ecosystem.

\section{New records}

The new recorded species in Marilog Forest Reserve Species include Pachyrhynchus erichsoni G.R. Waterhouse, M. geniculatus G.R. Waterhouse, $M$. kitangladensis Cabras et al. and $M$. ruficollis G.R. Waterhouse. Pachyrhynchus miltoni Cabras and Rukmane was recently discovered and recorded from the nearby localities which reflect the site endemicity of the species [16]. Ballentes et al. (2006) reported two species of Alcidodes spp. from the montane forest of Mt. Malindang which are unique morphologically to the four morpho-species recorded in this study. The present study documented 16 morphospecies which are unique in comparison to the species recorded from nearby locality [16]. These species are potential new to science. If proven, it could add to the hundred described species of Pachyrhynchus, Metapocyrtus, Desmidophorus, Polycatus and Peribleptus that are endemic in the archipelago.

\section{Plant Associates and Behavior}

A total of 22 species of plant associates are recorded. These include seven (7) species of ferns and 15 species of flowering plants (Table 
Table 1. Species richness and abundance of Weevils in Sitio Matigsalug, Marahan, Marilog Forest Reserve, Marilog District, Davao City, Mindanao, Philippines

\begin{tabular}{|c|c|c|c|}
\hline No. & Species & $\begin{array}{l}\text { Agroforest } \\
\text { Ecosystem }\end{array}$ & $\begin{array}{c}\text { Montane Forest } \\
\text { Ecosystem }\end{array}$ \\
\hline 1 & Alcidodes sp.1 & & 3 \\
\hline 2 & Alcidodes sp.2 & & 2 \\
\hline 3 & Alcidodes sp.3 & & 5 \\
\hline 4 & Alcidodes sp.4 & & 2 \\
\hline 5 & Desmidophorus sp. & 4 & \\
\hline 6 & Metapocyrtus apoensis Schultze, 1925 & 18 & \\
\hline 7 & Metapocyrtus geniculatus G.R.Waterhouse, 1842 & 22 & 3 \\
\hline 8 & Metapocyrtus kitangladensis Cabras et al. 2019 & & 4 \\
\hline 9 & Metapocyrtus ruficollis G.R.Waterhouse 1842 & 17 & \\
\hline 10 & Metapocrytus sp. 1 & 15 & \\
\hline 11 & Metapocrytus sp. 2 & 13 & 1 \\
\hline 12 & Metapocrytus sp. 3 & 28 & \\
\hline 13 & Metapocrytus sp. 4 & 21 & 1 \\
\hline 14 & Metapocrytus sp. 5 & 5 & 1 \\
\hline 15 & Metapocrytus sp. 6 & 8 & 2 \\
\hline 16 & Metapocrytus sp. 7 & 15 & 1 \\
\hline 17 & Metapocrytus sp. 8 & 10 & \\
\hline 18 & Pachyrhynchus erichsoni G.R.Waterhouse 1842 & & 3 \\
\hline 19 & Pachyrhynchus miltoni Cabras \& Rukmane, 2016 & & 2 \\
\hline 20 & Pachyrhynchus sp.1 & & 1 \\
\hline 21 & Peribleptus sp. & & 3 \\
\hline 22 & Polycatus sp. & 18 & \\
\hline
\end{tabular}

Table 2. Diversity indices of agroforest and montane forest ecosystem in Sitio Matigsalug, Marahan, Marilog Forest Reserve, Marilog District, Davao City, Mindanao, Philippines

Indices

Species abundance

Species Richness

Number of endemic species

Shannon-weiner diversity index
Agroforest Ecosystem

$\begin{array}{cc}194 & 34 \\ 13 & 15 \\ 13 & 15 \\ 1.07 & 1.12\end{array}$

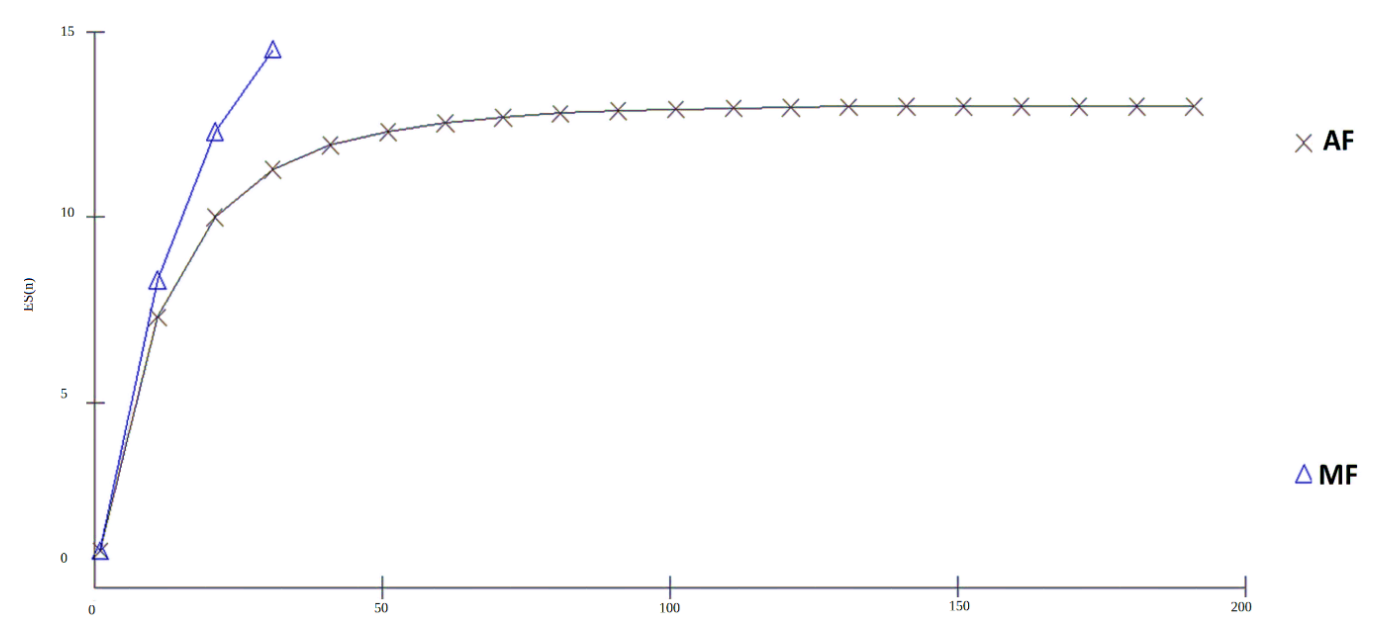

Figure 4. Species Accumulation Curve for agroforest (AF) and montane (MF) forests in Sitio Matigsalug, Marahan, Marilog District, Davao City, Mindanao 
3). Piper aduncum L. or locally known as Buyobuyo, an invasive alien species, is the most common plant associate. Eleven (11) species of weevils, all from genus Metapocyrtus, are observed in the plant which is mostly observed hiding in abaxial part of leaves (Figure 5 and 6). Reports have already proven that species belong to the genus are abundant especially in the lower elevation with intruding agricultural and invasive alien species such as Lantana camara L. and Impatiens balsamina Elm. Most of them are found feeding on these plants [15].

Some species of weevils in the agroforest are observed in the cultivated crop plants (e.g., Sechium edule (Jacq.) Swartz and Basella alba L.) of the local people. These include 7 species of Metapocyrtus and Polycatus sp. Findings have already reported that some Metapocyrtus species are pest to some crops and ornamental plants especially in lowland ecosystems [9]. Species mostly from the genus Metapocyrtus observed feeding on agricultural crops in lower elevations as these areas are used to be an intact forest converted to agricultural lands.

Nine (9) species of weevils are perching on ferns mostly on Dicranopteris linearis (Burm.f.) Underw., locally known as Agsam, which is common in the area widely used for handicraft making by the indigenous people. Most of the species observed are on top of leaves and some

Table 3. Associated plants and observed activities of weevils from Sitio Matigsalug, Marahan, Marilog Forest Reserve, Marilog District, Davao City, Mindanao, Philippines

\begin{tabular}{|c|c|c|c|}
\hline Species & $\begin{array}{c}\text { Relative } \\
\text { Abundance } \\
(\%)\end{array}$ & Associated Plants & Activities \\
\hline Alcidodes sp.1 & 1.32 & $\begin{array}{l}\text { Christella parasitica (L.) H. } \\
\text { Lev. } \\
\text { Cyclosorus sp. }\end{array}$ & $\begin{array}{l}\text { Atop frond, Perched on leaf } \\
\text { axil, possibly feeding, } \\
\text { partially hidden between } \\
\text { fronds, atop stipe, atop twig } \\
\text { of dried plant }\end{array}$ \\
\hline Alcidodes sp.2 & 0.88 & $\begin{array}{l}\text { Christella parasitica (L.) H. } \\
\text { Lev. }\end{array}$ & Atop frond, atop stipe \\
\hline Alcidodes sp.3 & 2.19 & $\begin{array}{l}\text { Medinilla sp. } \\
\text { Begonia sp. }\end{array}$ & Atop leaf \\
\hline Alcidodes sp.4 & 0.88 & Medinilla sp. & Atop leaf \\
\hline Desmidophorus sp. & 1.75 & Sphaerostephanos sp. & Atop frond \\
\hline $\begin{array}{l}\text { Metapocyrtus } \\
\text { apoensis } \\
\text { Schultze, } 1925\end{array}$ & 7.89 & $\begin{array}{l}\text { Mangifera sp. } \\
\text { Piper aduncum L. } \\
\text { Zingeberaceae } \\
\text { Costus sp. }\end{array}$ & $\begin{array}{l}\text { Partially hidden on abaxial } \\
\text { part of the leaf, atop frond } \\
\text { and copulating }\end{array}$ \\
\hline $\begin{array}{l}\text { Metapocyrtus } \\
\text { geniculatus } \\
\text { G.R.Waterhouse, } \\
1842\end{array}$ & 10.96 & $\begin{array}{l}\text { Piper aduncum L. } \\
\text { Christella parasitica (L.) H. } \\
\text { Lev. }\end{array}$ & $\begin{array}{l}\text { Atop leaf, atop frond and } \\
\text { copulating }\end{array}$ \\
\hline $\begin{array}{l}\text { Metapocyrtus } \\
\text { kitangladensis } \\
\text { Cabras et al. } 2019 \\
\end{array}$ & 1.75 & $\begin{array}{l}\text { Piper aduncum L. } \\
\text { Impatiens balsamina Elm. } \\
\text { Zingeberaceae }\end{array}$ & Atop leaf \\
\hline $\begin{array}{l}\text { Metapocyrtus } \\
\text { ruficollis } \\
\text { G.R.Waterhouse } \\
1842\end{array}$ & 7.46 & $\begin{array}{l}\text { Dicranopteris } \\
\text { (Burm.f.) Underw. } \\
\text { Piper aduncum L. } \\
\text { Bambusa sp. }\end{array}$ & Atop frond and copulating \\
\hline Metapocrytus sp. 1 & 6.58 & $\begin{array}{l}\text { Piper aduncum L. } \\
\text { Bambusa sp. } \\
\text { Alocasia sp. } \\
\text { Musa paradisiaca L. }\end{array}$ & Atop leaf \\
\hline
\end{tabular}


Continue of Table $3 \ldots$

\begin{tabular}{|c|c|c|c|}
\hline Species & $\begin{array}{c}\text { Relative } \\
\text { Abundance } \\
(\%)\end{array}$ & Associated Plants & Activities \\
\hline & & Sechium edule (Jacq.) Swartz & \\
\hline Metapocrytus sp. 2 & 6.14 & $\begin{array}{l}\text { Piper aduncum L. } \\
\text { Impatiens balsamina Elm. } \\
\text { Basella alba L. }\end{array}$ & $\begin{array}{l}\text { Atop leaf, atop frond and } \\
\text { copulating }\end{array}$ \\
\hline Metapocrytus sp. 3 & 12.28 & $\begin{array}{l}\text { Piper aduncum L. } \\
\text { Medinilla spp. } \\
\text { Schefflera sp. } \\
\text { Sechium edule (Jacq.) Swartz }\end{array}$ & $\begin{array}{l}\text { Partially hidden on abaxial } \\
\text { part of the leaf }\end{array}$ \\
\hline Metapocrytus sp. 4 & 9.65 & $\begin{array}{l}\text { Piper aduncum } \mathrm{L} \text {. } \\
\text { Impatiens balsamina } \\
\text { Elm. }\end{array}$ & $\begin{array}{l}\text { Atop twig of dried plant, } \\
\text { atop leaf }\end{array}$ \\
\hline Metapocrytus sp. 5 & 2.63 & $\begin{array}{l}\text { Piper aduncum L. } \\
\text { Nephrolepis bisserata (Sw.) } \\
\text { Schott } \\
\text { Sechium edule (Jacq.) Swartz }\end{array}$ & Atop leaf \\
\hline Metapocrytus sp. 6 & 4.38 & $\begin{array}{l}\text { Piper aduncum L. } \\
\text { Rubus sp. } \\
\text { Amyema sp. }\end{array}$ & Atop frond and copulating \\
\hline Metapocrytus sp. 7 & 7.02 & $\begin{array}{l}\text { Piper aduncum L. } \\
\text { Zingeberaceae } \\
\text { Dicranopteris } \quad \text { linearis } \\
\text { (Burm.f.) Underw. } \\
\text { Sechium edule (Jacq.) Swartz }\end{array}$ & Atop leaf \\
\hline Metapocrytus sp. 8 & 4.39 & $\begin{array}{l}\text { Piper aduncum L } \\
\text { Angiopteris sp. } \\
\text { Tridax procumbens } \\
\text { Sechium edule (Jacq.) Swartz }\end{array}$ & $\begin{array}{l}\text { Partially hidden on abaxial } \\
\text { part of the leaf }\end{array}$ \\
\hline $\begin{array}{l}\text { Pachyrhynchus } \\
\text { erichsoni } \\
\text { G.R.Waterhouse } \\
1842 \\
\end{array}$ & 1.32 & Shrub & Atop leaf \\
\hline $\begin{array}{l}\text { Pachyrhynchus } \\
\text { miltoni } \\
\text { Cabras \& Rukmane, } \\
2016\end{array}$ & 0.88 & $\begin{array}{ll}\text { Dicranopteris } & \text { linearis } \\
\text { (Burm.f.) Underw. }\end{array}$ & Atop stipe \\
\hline Pachyrhynchus sp.1 & 0.44 & Asplenium nidus L. & $\begin{array}{l}\text { Atop leaf with a fungus } \\
\text { attached on its hind tarsus }\end{array}$ \\
\hline Peribleptus sp. & 1.32 & $\begin{array}{l}\text { Poaceae } \\
\text { Artocarpus sp. }\end{array}$ & $\begin{array}{l}\text { Perching on a branch and } \\
\text { some on top of leaves }\end{array}$ \\
\hline Polycatus sp. & 7.89 & $\begin{array}{l}\text { Shrub } \\
\text { Basella alba L. }\end{array}$ & $\begin{array}{l}\text { Partially hidden on abaxial } \\
\text { part of the leaf }\end{array}$ \\
\hline
\end{tabular}




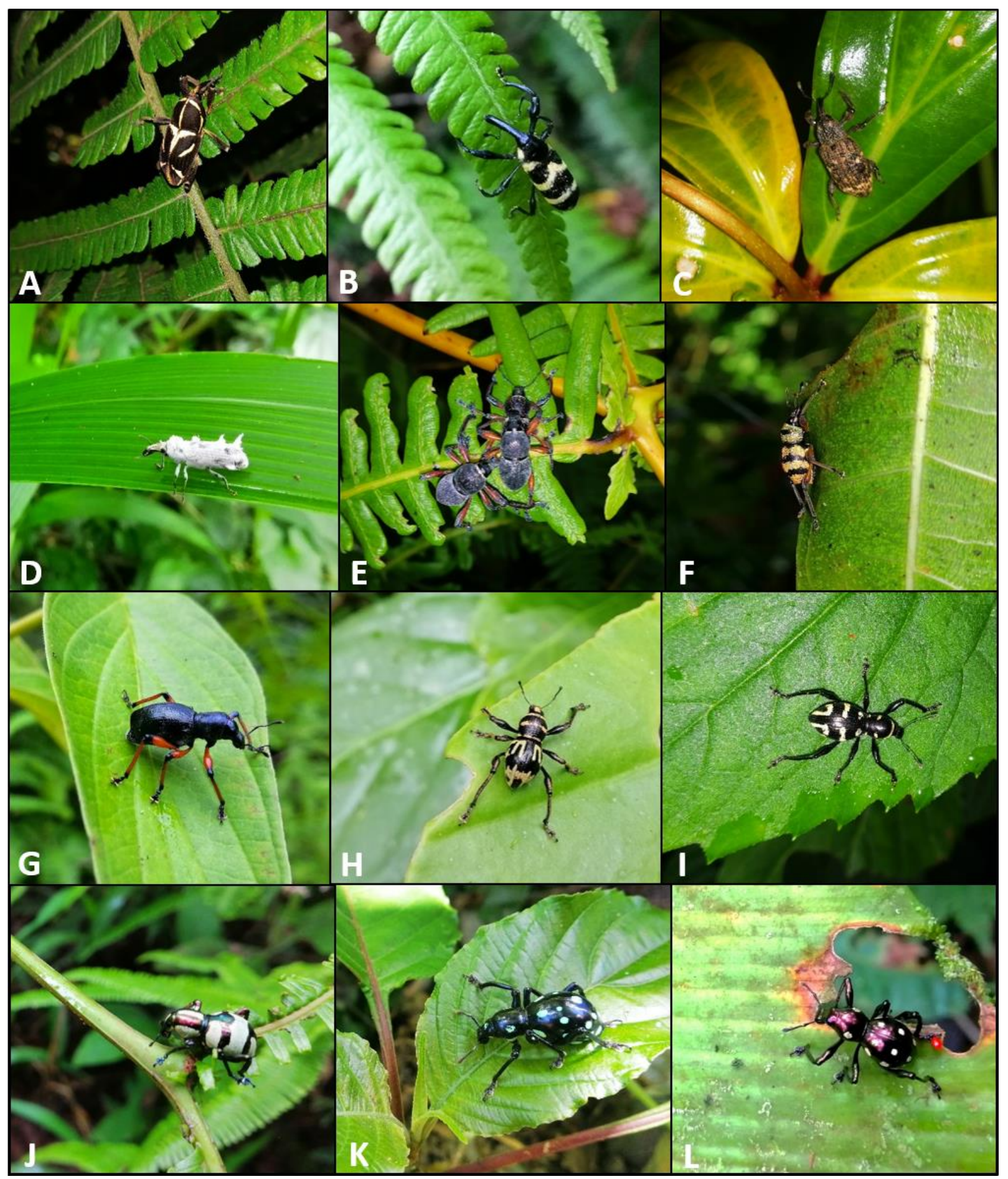

Figure 5. Some species of weevils in Sitio Matigsalug, Marilog Forest Reserve, Marilog District, Davao City, Mindanao, Philippines. A. Alcidodes sp. 1; B. Alcidodes sp. 2; C. Alcidodes sp. 3; D. Peribleptus sp.; E. Metapocyrtus ruficollis; F. Metapocyrtus apoensis; G. Metapocrytus geniculatus; H. Metapocyrtus sp.1; I. Metapocyrtus sp.2; J. Pachyrhynchus miltoni; K. Pachyrhynchus erichsoni and L. Pachyrhynchus sp. 


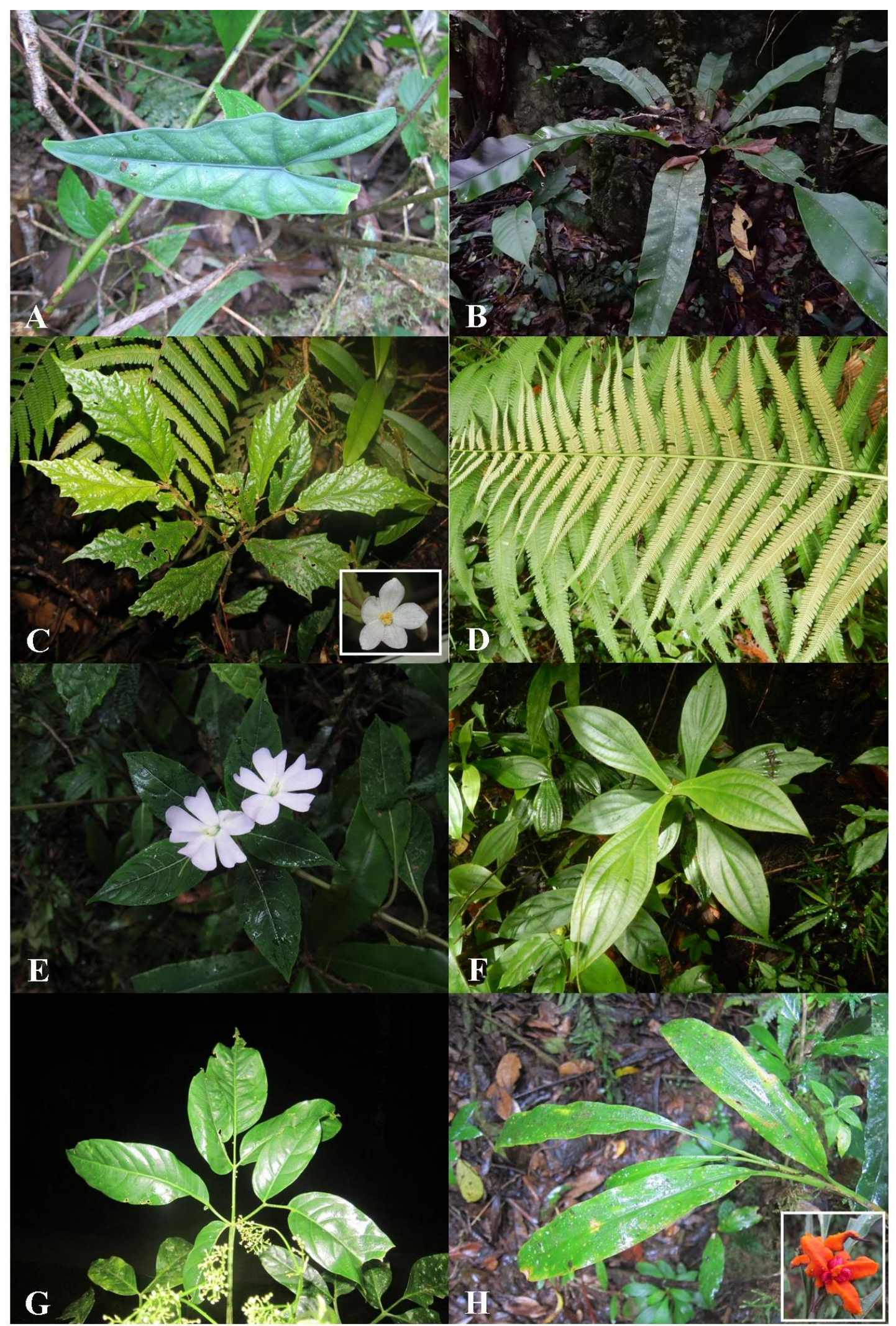

Figure 6. Some plant associates of weevils from Sitio Matigsalug, Marahan, Marilog Forest Reserve, Marilog District, Davao City, Mindanao, Philippines. A. Alocasia sp.; B. Asplenium nidus L.; C. Begonia sp.; D. Cyclosorus sp.; E. Impatiens balsamina Elm.; F. Medinilla sp.; G. Schefflera sp. and H. Zingeberaceae. 
are partially on the abaxial while others are on the branch. Although Pachyrhynchus species are not observed in agroforest ecosystem, there are reports shows that they are infesting fruit trees [18]. There are 5 species observed copulating mostly on top of leaves. All of which are from genus Metapocyrtus which observed mostly in agroforest ecosystem. This observation explains the big difference in species abundance of the genus between the agroforest and montane forest ecosystems.

\section{Conclusion}

Study revealed high species abundance and richness both in agroforest and montane forest of Sitio Matigsalug, Marahan with a total of 228 individuals distributed to 22 species and six genera. Alcidodes, Pachyrhynchus, Peribleptus and some Metapocrytus preferred montane forest habitat while Desmidophorus, Polycatus and most of Metapocyrtus explored the agroforest ecosystem. Most of the species are also unique which implies the site endemicity and restricted distribution in the area. Weevils also vary when it comes to their plant associates with a total of 22 species. Most of the observed weevils were hiding in leaves while some are observed copulating and possibly feeding. These species of plants and vegetation as a whole has a vital role in the survival of not just weevils but also other group of fauna in the area. Anthropogenic disturbances specifically agricultural activities and clearing of forest area must be minimized. Protection and conservation initiatives are highly recommended to save the remaining flora and fauna in Sitio Matigsalug, Marahan, Marilog District.

\section{Acknowledgment}

The authors would like express gratitude to the DARE TO (Discovery-Applied Research and Extension for Trans/Interdisciplinary Opportunities) program entitled Saving Terrestrial Biodiversity: inventory, Assessment, Conservation and Capability Building in Marilog Forest Reserve, Southern Mindanao, Philippines of the Commission on Higher Education (CHED) for funding this research; to the MAMATRIPCEDI (Matigsalug-Manobo Tribal People Council of Elders Davao Inc.) and to the local researchers of Marilog District, Davao City, Southern Mindanao. The Department of Environment and Natural Re- sources Region XI for the Gratuitous Permit (GP). We would like also to thank our University President Dr. Jesus Antonio G. Derije for his help in implementing our research project.

\section{References}

1. Mittermeier RA, Myers N, Thomsen JB et al. (1998) Biodiversity hotspots and major tropical wilderness areas: approaches to setting conservation priorities. Conservation Biology 12: 516-520.

2. Ballentes M, Mohagan A, Gapud V et al. (2006) Arthropod Faunal Diversity and Relevant Interrelationships of Critical Resources in Mt. Malindang, Misamis Occidental. Southeast Asian Regional Center for Graduate Study and Research in Agriculture (SEARCA) 1166. ISBN971-560-125-1.

3. Barsevskis A (2016) New Species of Pachyrhynchus Germar, 1824 and Macrocyrtus Heller, 1912 (Coleoptera: Curculionidae) from the Marinduque Island (Philippines) As A New Example of Mimetic Species Pair. Acta Biologica Universitatis Daugavpils 16 (1):1-6.

4. Oberprieler R, Marvaldi A, Anderson R (2007) Weevils, Weevils, Weevils Everywhere. Zootaxa 1668: 491520 .

5. Yoshitake H (2012a) Metapocyrtus (Trachycyrtus) hederaephilus sp. nov. (Coleoptera: Curculionidae: Entiminae), a pest of the English ivy cultivated in Mie Prefecture Honshu Japan. Japanese journal of Systematic Entomology 18 (2): 261 - 267. 18.

6. Yoshitake H (2012b) Nine New Species of the Genus Pachyrhynchus Germar (Coleoptera: Curculionidae) from the Philippines. Esakia (52): 17-34.

7. Bollino M, Sandel F (2015) Three New Species of the Genus Pachyrynchus Germar, 1842 from Lubang Island (Philippines) (Coleoptera: Curculionidae: Pachyrynchini). Munis Entomology and Zoology Journal 10 (2): $392-401$.

8. Rukname A, Barsevskis A (2016) Nine new species of the genus Pachyrhynchus Germar, 1824 (Coleoptera: Curculionidae) from the Philippines. Baltic Journal of Coleopterology 16 (1): 77 - 96. 12.

9. Rukname A (2016) Six New Species of the Genus Pachyrhynchus Germar, 1824 (Coleoptera: Curculionidae) from the Philippines. Acta Biologica Universitatis Daugavpils 16 (1): 81 - 92.

10. Cabras AA, Rukmane A (2016) A new species of Pachyrhynchus Germar, 1824 (Coleoptera: Curculionidae: Entiminae). Acta Biologica Universitatis Daugavpils $16(1)$ : $123-127$.

11. Cabras AA, Medina MND, Zhang G (2019) Metapocyrtus kitangladensis sp. n., a new Pachyrhynchus 
cumingii GR Waterhouse, 1841 mimic from Mindanao Island, Philippines. Zookeys 853: 119 - 129.

12. Medina MND, Cabras AA (2018) Metapocyrtus (Artapocyrtus) willietorresi sp. n. (Coleoptera: Curculionidae) from Southern Mindanao (Philippines), with notes on its ecology and mimicry complex. Baltic Journal of Coleopterology 18 (2): 185 - 192.

13. Yap SA, Gapud VP (2007) Taxonomic review of the genus Metapocyrtus Heller (Coleoptera: Curculionidae: Entiminae: Pachyrrhynchini). Philippine Entomology 21: 115 - 135.

14. Cabras A, Nique G, Mohagan A (2016) Diversity and Distribution of Pachyrynchini (Coleoptera: Curculionidae: Entiminae) in Mt. Apo, Natural Park, Philippines. Journal of Biodiversity and Environmental Science 8 (2): 312 - 319.

15. Cabras A, Coritico F, Mohagan A, Rukmane A (2017) Diversity of Pachyrynchini (Coleoptera: Curculionidae: Entiminae) in Mt. Kiamo, Malaybalay, Bukidnon, Mindanao, Philippines. Journal of Entomology and Zoology Studies 5 (3): 979-983.
16. Mohagan AB, Patano RP Jr, Hongco A et al. (2018) Species occurrence of weevils (Coleoptera: Curculionidae) in the Baganihan, Marilog Forest Reserve, Marilog District, Davao City, Philippines. Journal of Biodiversity and Environmental Sciences 13 (2): 30 - 34.

17. Heyer WR, Donnelly MA, McDiarmid RW, Hayek LAC, Foster MS (1994) Measuring and Monitoring Biological Diversity: Standard Methods for Amphibians. Washington D.C., USA: Smithsonian Institution Press.

18. Schultze W (1923) A monograph of the Pachyrrhynchid group of the Brachyderinae, Curculionidae: Part I. Philippine Journal of Science 23: 609-673 + 6 pls.

19. Hong KJ, Park S, Kim T (2011) A New Record of the Family Brachyceridae (Coleoptera: Curculionoidea) and a New Species, Desmidophorus hebes (Fabricius), in Korea. Korean Journal of Applied Entomology 50(3): 179 - 184.

20. Heller KM (1992) New Philippine Coleoptera. Philippine Journal Science 19 (5): 523-627. 